\title{
Biochemical analysis of Brachystegia aurycoma harms seeds
}

\author{
S. O. Babajide, **S. A. Oluwalana and *O. A. Akinlawon \\ *Department of Science Laboratory Technology. Moshood Abiola Polytechnic, Abeokuta, Nigeria \\ **Department of Forestry and Wildlife Management. University' of Agriculture, Abeokuta, Nigeria
}

\begin{abstract}
A biochemical analysis of Brachnstegia aurvioma harm seeds was conducted. Brachystegia, of the family Leguminosae sub-family. Caesalpinioidae is a timber tree whose seeds "achi", are relished as soup condiment by the Igbo-speaking people of Nigeria. The seed were subjected to oil extraction using Soxhlet method. The oil was subjected to chemical analysis to determine the saponification. iodine, free fatty acid and acid values. Proximate analysis w'as carried out on the seed meal and the seed coat. Results show'ed that the oil content was 3.33\% which is of good quality and fit for human consumption. The saponification value was $287.85 \mathrm{mg} / \mathrm{KOH} / \mathrm{g}$, Free fatty acid value $6.73 \mathrm{mg} / \mathrm{KOH} / \mathrm{g}$. and iodine value $132.08 \%$. The proximate analysis of the seed meal showed that the moisture content 1'<is $15.77 \%$, ash $25 \%$, protein $1+25 \%$, crude fibre $19.05 \%$ and nitrogen free extractives (carbohydrates) $21.58 \%$. It show's the seed meal as good source of plant protein and energy and of high roughage and mineral content. The proximate analysis of the seed coat showed that the ash content was $8.33 \%$. The calcium and magnesium contents were 30.00 and $18.00 \%$ respectively: This shows that the seed coat can be a supplement in lirestock feed.
\end{abstract}

Keywords: Brachystegia, seeds, chemical analysis

\section{Introduction}

From time immemorial mankind largely depended on biological diversities for food, shelter, clothing (Abebe, 1994) and many other products. Forest plants are the basis of a wide variety of goods ranging from food. phytopharmaceuticals. herbal remedies, perfumes. cosmetics. colouring agents. detergents, liquers, varnishes and fireworks (Lange and Schippmann, 1997). In the tropical rainforest regions, leaves and seeds are essential ingredients of a daily diet all year round. The leaves and seeds add diversity and flavour to the diet (Fleuret, 1979). Africans alone consume over 1500 species of wild plants and seeds (Okigbo, 1983).

Seeds and nuts generally provide calories, oil and protein to the diet. Seeds crops have been cultivated since antiquity. Sesame seed was known in ancient times and repeseed was mentioned in the lndian Sanskirt writing of 2000 B. C. (Hatje, 1989) and Soybeans have been an important staple food in China for thousands of years. which today accounts for more than 50 percent of the world's oilseed output while sunflower seed and rape seed account for a further 19 percent (Hatje, 1989). In the tropics. cacao and coffee are two major seed products 


\section{Babajide, Oluwalana and Akinlawon}

that are internationally known and traded. These two are not consumed by the people themselves but are grown as cash crops. However, there are several plants that are exploited for their seeds. One of such plants is Brachystegia aurycomas harms. Brachystegia aurycoma harm is a tree common in intermediate and fringing forests, often in swampy places. It is gregarious, and may be readily recognized by its large size, irregular bole and huge twisted spreading branches forming a canopy, and by the rough fibrous bark which peels up in woody patches and often exudes a brownish buttery gum (Keay, 1989). Brachystegia aurycoma can grow up to $36 \mathrm{~m}$ high and $8 \mathrm{~m}$ in girth. It flowers between April and May. Fruiting is between September and January. The number of seeds per kilogram is 1,500-2,600. Under ideal situation germination with good seeds gives $80 \%$ germination rate in 20-21 days. The seeds can retain viability for one year if kept free from insects (Burkill, 1985). In Nigeria, Brachystegia aurycoma Harms is known by many vernacular names. In Yoruba, it is called "Eku-akolodo", Benin as "Okwein" or "Okwen"; Ijaw as "akapakpa". "apaupau"; Efik as "Ukung", and in lbo as "ach"". The name sachir has become popular because of the commercialization of the seeds by the lbo people, who use the seeds as soup condiment.

The analysis of Brachystegia aurycoma Harms seeds became imperative in order to ascertain its suitability for human consumption, and as livestock feed supplement. In addition, to add to the body of knowledge in plant diversity utilization in the tropics.

\section{Materials and method}

Seeds of Brachystegia aurycoma Harms were bought from local market, dried and weighed until a constant weight was obtained. The dried seeds were dehulled and the coat collected separately. The seeds were ground to increase the surface area in order to enhance total extraction of oil present in the seed. The oil was extracted using Soxhlet extractor and petroleum ether as the solven. (Davis, 1978). Standard methods of analysis were used to analyze saponification value, free fatty acid value, and iodine value.

Complexometric titration was carried on the grounded seed coat using ethylene diamine tetra acetic acid to titrate against the prepared solution of the sample and Eriochrome black $T$ as the indicator to determine the calcium and magnesium content of the seed coat. The meal obtained after oil extraction was subjected to proximate analysis to determine protein, crude fibre and carbohydrate content.

\section{Results and discussion}

The results of the chemical analysis of the nutritional factors are presented in Table 1. The $3.33 \%$ oil yield is very low when compared with that of Soyabean (25\%) and Jatropha curcas which is $36 \%$ (Odeseye, 1996), coconut copra which has a value of $65-70 \%$ (Theme, 1968). Also, it is considerably lower than the values for tobacco seed $(33-43 \%)$, conophor oil from the walnut plant Tetracarpidium conophorum (44$50 \%)$, Rubber seed (21-25\%) and Castor (Ricimus communis) which has a value of $35-$ $55 \%$. Therefore the production of oil from Brachystegia seeds seems to be expensive and uneconomical for domestic use.

The moisture content obtained was $15.79 \%$. This low figure signities that the seeds will dry and store well. The value is however higher than those for nibber seed without shell, groundnut seed without bull soybears whole seed, and cotton seed which are $3.39,5.4,10.0$, and $7.3 \%$ respectively (Onuwaje and Imoukhuede, 1986).

The ash content of $25 \%$ is relatively high implying high mineral content in the seed. The ash content of the seed is higher than that of cassava which is $11 \%$ (Adebambo, 1997). 


\section{Chemical composition of Brachystegia aurycoma seeds}

Table 1 Proximate analysis of Brachystegian aurycoma harms seed meal

\begin{tabular}{ll}
\hline Nutrient & Contents(\%) \\
\hline Oil & 3.33 \\
Moisture & 15.79 \\
Ash & 25.00 \\
Protein & 14.25 \\
Crude Fibre & 19.05 \\
NFE (Total carbohydrate) & 21.58 \\
\hline
\end{tabular}

The crude protein content was $14.0 \%$ and as a plant protein source, this is relatively high. However, this is low when compared with other seed meals such as soyabean seed protein which is $30-40 \%$ (Rehm and Espig, 1991) and coconut copra protein which is $20 \%$ (Hagenmaier, 1980). But the Brachystegia seed meal apart from serving as soup condiment can also be used as complementary ingredient in livestock feeds.

However, there are many factors that would need investigation. The quantity of harvested seeds should be known, so also is the cost of procuring the needed quantity which ultimately would affect the supply and demand for the seeds.

The crude fibre content of $19.05 \%$ is high, indicating a high roughage content and low or poor digestibility. However, this can be of nutritional significance as it helps to prevent many metabolic or digestive disorders such as constipation and irritation.

The Nitrogen free extract content (NFE) is $21.58 \%$. NFE is a measure of the food, that is, the carbohydrate content. This is comparable to the carbohydrate contents. This is comparable to the carbohydrate contents of groundnut seed (without hull), Soyabean whole seed, and cotton whole seed with values of $11.70,24.50$ and
$26.30 \%$ respectively (Onuwaje and Imoukhuede, 1986). Brachystegia seed meal can be a source of energy to both man and livestock.

Table 2 gives the result of the various tests on the oil. The $287.85 \mathrm{mg} / \mathrm{KOH} / \mathrm{g}$ saponification value (SV) obtained for Brachystegia seed oil is higher than the SV of coconut oil (245.27) palm kernel oil (240-255), palm oil (185-205), groundnut oil (185-195). It is also higher than those of soyabean oil (185-195), sunflower oil (185-195), cotton seed oil (190-200), maize oil (185-195), olive oil (185-195), (van Der vet, 1968) and rubber seed oil (171.26). Nwokolo and Akpakunam, 1986), It can be concluded that Brachystegia oil is of high molecular weight.

The free fatty acid value obtained for Brachystegia seed oil was $3.16 \%$. This is an important variable in considering the quality of oil for human consumption. The lower the free fatty acid, the better the quality of the oil.

The acid value of Brachystegia seed oil is $6.73 \mathrm{mg} / \mathrm{KOH} / \mathrm{g}$. Acid value of oil or fat indicates the quality of fatty substance. The higher the fatty acid present in oil, the greater the acid value. This value is comparable to the acid values of edible oils such as palm oil and cotton seed oil with $10 \mathrm{mg} / \mathrm{KOH} / \mathrm{g}$, and $4-10 \mathrm{mg} / \mathrm{KOH} / \mathrm{g}$ respectively.

The iodine value obtained for Brachystegia oil was $132.08(\mathrm{mg} / \mathrm{g})$. Iodine value measures the level or degree of unsanurated fatty acids in an oil (Meyer, 1978). When compared with the iodine values of other oils, soyabean oil (125-140 $\mathrm{mg} / \mathrm{g})$, sunflower oil (125-135 mg/g), cotton seed oil $(100-115 \mathrm{mg} / \mathrm{g})$ and maize oil (105-130 $\mathrm{mg} / \mathrm{g}$ ) (van Der Vet, 1968), Brachystegia seed oil is relatively good. 


\section{Babajide, Oluwalana and Akinlawon}

Table 2 Chemical characteristics of Brachystegia aurycoma harms seed meal

\begin{tabular}{ll}
\hline Test & Values \\
\hline Saponification $(\mathrm{S})(\mathrm{Mg} / \mathrm{KOH} / \mathrm{g})$ & 287.85 \\
Free Fatty Acid $(\%)$ & 3.16 \\
Acid $(\mathrm{Mg} / \mathrm{KOH} / \mathrm{g})$ & 6.73 \\
Iodine $(\mathrm{mg} / \mathrm{g})$ & 132.08 \\
\hline
\end{tabular}

Table 3 Ash, calcium and magnesium content of Brachstegian aurycoma harms seed coat

\begin{tabular}{ll}
\hline Measurement & Content $(\%)$ \\
\hline Total Ash & 8.33 \\
\hline Calcium & 30.00 \\
Magnesium & 18.00 \\
\hline \hline
\end{tabular}

However, the oil is likely to solidify at room temperature due to the large amount of saturated fatty acid. The results of the proximate analysis of the Brachystegia seed coat are presented in Table 3. The total ash content of the seed coat was $8.33 \%$. The calcium and magnesium contents in the ash were 30 and $18 \%$ respectively.

\section{Conclusion}

From the results obtained, Brachystegia seeds seem very promising as a source of feed for livestock. Though not so rich in oil, the oil content nevertheless could be a source of vegetable oil for both domestic and industrial use. However, for a definite projection on the use of Brachystegia seed for livestock feed to be made, a number of problems will need to addressed. These problems include: availability of seeds in adequate quantities, and storage. It would be necessary to investigate the seed production potential of Brachystegia and the shelf life of the seed to determine if serious deterioration occurs which may have serious implications on its level of application in livestock feeding.

\section{References}

Abebe, D. 1994. Biodiversity conservation and medicinal plants. In: J. H. Seyanni and A. C. Chikuni, Proc. XIIIth Plenary meeting AETFAT, Malawi 1: 191 - 196 (1994).

Burkill, H. M. 1985. The useful plants of West Tropical Africa. Edition 2, Vol. 1,

Davis, B. 1978. Food commodities, fourth edition, Heinemann Publishers, London $346 p$.

Fleuret, A. 1979. The role of wild foliage in the diet. A case study from Lushoto, Tanzania. Ecology of food and nutrition. 8(2): 87-93.

Hagenmaier, R. 1980. Coconut aquous processing. $2^{\text {nd }}$ Ed. San Carlos, Cebu city, Philipines.

Hatje, G., 1989. World importance of oil crops and their products. In: Oil crops of the world Robbelen, G., Downey, R. K. and A. Ashri (Eds). McGraw-Hill Publ. Co., New York pp. $1-21$.

Keay, R. W. J. 1989. Trees of Nigeria. Clarendon Press, Oxford, 476p. 


\section{Chemical composition of Brachystegia aurycoma seeds}

Lange, D. and Schippmann, U., 1997. Trade survey of medicinal plants in Germany. A contribution to international plant species conservation. BonnBad. Godesberg, Germany.

Meyer, L. G. 1978. Food Chemistry. The Avi publishing Co., Inc. Connecticut. U. S. A. $385 \mathrm{p}$.

Nwokolo, E., and Akpakunam, 1986. Chemical and biological evaluation of rubber seed meal. In Industrial Utilization of Natural Rubber (Hevea brasiliensis) Seed, Latex and Wood E. E. Enabor (Ed.) Rubber Research. Institute of Nigeria, Benin city, Nigeria. PP 54-61.

Okigbo, B. N. 1983. Fruits and vegetable, production and extension services in Africa. Acta Horticulture 123:23-27.
Onwaje, O. U. and Imoukhuede, S. K. 1986. Rubber (Hevea brasiliensis) Seed Meal. A potential material for livestock diets in Nigeria. In : Industrial Utilization of National Rubber (Hevea brasiliensis) Seed, Latex and Wood. E. E. Enabor (Ed.) Rubber Research Institute of Nigeria, Benin City, Nigeria PP. $47-53$.

Rehm, S. and Espig, G. 1991. The cultivated plants of the tropics and subtropics. Verlag Josef margraf Scientif Books, Germany. $552 \mathrm{p}$.

Theme, J. G. 1968. Coconut oil processing FAO Agric. Devel. Paper 89, FAO, Rome.

Van Der Vet, A. P. 1968. Edible fats and oils. In: quality control in the Food Industry. Herschdoerfer, S. M. (Ed.) Vol. 2. Academic Press, London New York. PP $355-406$. 